Dept. of Food Hygiene and Control

Fac. Vet. Med., Beni-Suef University

\title{
SERO-DIAGNOSIS OF BRUCELLOSIS IN COWS BY USING MILK
}

(With 2 Tables)

\author{
By
}

\section{A.M. EL-KHOLY; A.M.S. MESHREF and G.M. HASSAN \\ (Received at 6/3/2008)}

\section{التشخيص السيرولوجى لمرض البروسيلا فى الابقار بواسطة اللبن

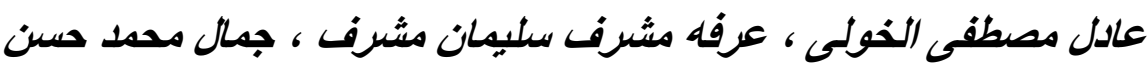

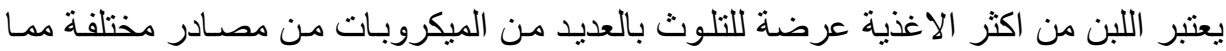

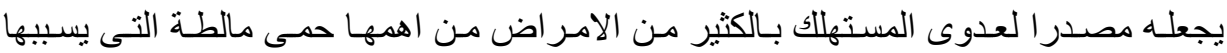

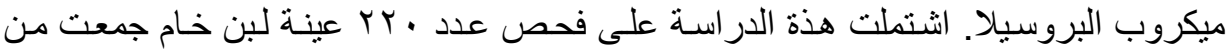

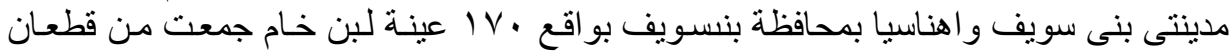

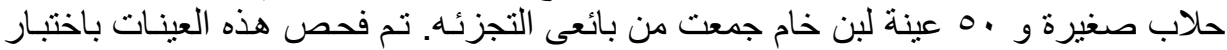

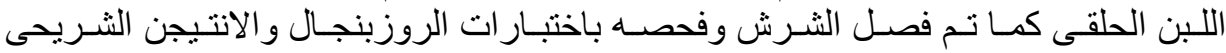

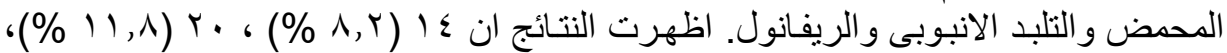

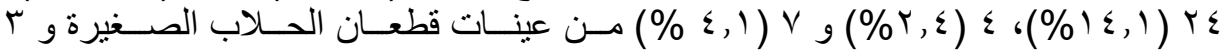

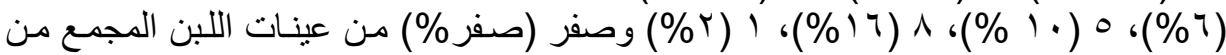

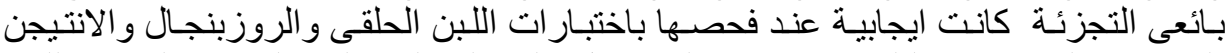

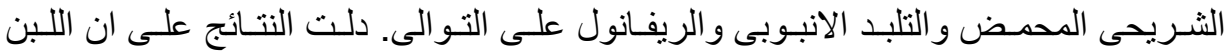

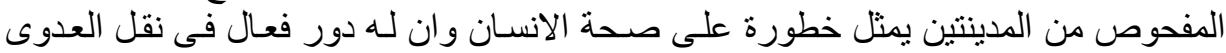

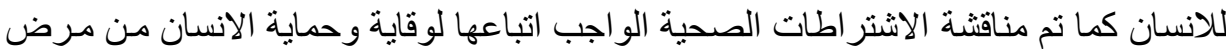

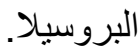

\section{SUMMARY}

A total of 220 raw milk samples were collected randomly from BeniSuef and Ehnasia cities in Beni-Suef Governorate, comprising 170 small dairy herd and 50 retail milk samples. All the samples were examined serologically for brucellosis using MRT, wRBPT, w BAPAT, wTAT and $\mathrm{w}$ Riv.T. The results revealed that 14 (8.2\%), 20 (11.8\%), $24(14.1 \%), 4(2.4 \%)$ and $7(4.1 \%)$ out of 170 small dairy herds milk samples were positive respectively. On the other hand, $3(6 \%), 5(10 \%)$, $8(16 \%), 1(2 \%)$ and $0(0 \%)$ out of 50 retail milk samples were positive for MRT, wRBPT, w BAPAT, wTAT and w Riv.T respectively. The results indicated that the milk of small dairy herds and retailers in both 
examined cities play a dangerous role in transmitting infection to human and constitute a public health hazard. The necessary measures to control the disease were discussed

Key words: Brucellosis, milk, cows

\section{INTRODUCTION}

Brucellosis is a widely prevalent bacterial zoonotic disease especially in the Mediterranean area and developing countries. It is responsible for serious economic losses for dairy industry due to losses of calves, reduction in milk yield by $7-20 \%$, some breeding troubles in infected animals and veterinary costs of diagnosis and preventive control measures (Sanders, 1989). Brucellosis is usually transmitted to humans either directly through contact with infected animals or their discharges or indirectly through ingestion of contaminated raw milk and dairy products prepared from unpasteurized milk (Sutra et al., 1986 and Altuglu et al., 2002).

Diagnosis of brucellosis is the corner stone for proper eradication of the disease. Isolation of the causative agent is still the land mark for proper diagnosis, but because of cost, time consuming, difficulty of performance, lack of sensitivity of most culture procedure and intermittent nature of its excretion in milk, the serological diagnosis is the main tool used for the detection of brucella infected animals. Although a wide range of serodiagnostic tests are available, there is no single test capable to identify the infected animals (Morgan et al., 1969, Davies, 1971 and Salem et al., 1987).

On the other hand, milk constitutes a highly desirable source of antibody for routine screening purposes and for the identification of infected individuals since sample collection is simple, not critical, less expensive, its antibody levels correlate with serum levels and single test can be applied to large numbers of cattle (Boraker et al., 1981, Smith et al., 1989 and Nielsen et al., 1996).

In Egypt, milk is produced mainly by individual owners in small farms that lack of proper sanitary measures, which may be either consumed fresh, manufactured into dairy products or sell in retail markets. Therefore the present study is designed to declare the milk sero-prevalence and risk of brucellosis in Beni-Suef and Ehnasia cities in Beni-Suef governorate and to throw the light upon the public health significance and preventive measures to control brucellosis.

\section{MATERIALS and METHODS}




\section{1- Sampling:}

A total of 220 raw milk samples were collected randomly from Beni-Suef and Ehnasia cities in Beni-Suef Governorate, comprising 170 small dairy herd milk samples (each sample contain the pooled milk of 3-5 animals) and 50 retail milk samples.

All samples were collected after thorough mixing without adding any preservatives and transferred directly to the laboratory in an insulating ice-box and kept in refrigerator until examination.

In case of small dairy herds all samples were collected from cows nearly in the mid lactation, free from subclinical mastitis and not receive any hormonal medication.

\section{2- Preparation of whey:}

Milk whey was prepared from the collected milk samples according to Morgan, et al. (1978).

\section{3- Antigens:}

All the antigens used throughout the work were donated from the Abassia Veterinary Research Institute, Cairo, Egypt, including:

a- Milk ring test antigen.

b- Rose Bengal plate test antigen.

c- Buffered acidified plate antigen.

d- Rivanol test antigen and Rivanol solution.

e- Tube agglutination test antigen.

\section{4- Methods:}

Milk ring test (MRT), whey Rose Bengal plate test (wRBPT), whey Buffered acidified plate antigen test (wBAPAT), whey Tube agglutination test (wTAT) European method were carried out according to Alton, et al. (1988), while whey Rivanol test (wRiv.T) was performed according to National Veterinary Services Laboratories, Ames, Iowa, USA (1984).

\section{RESULTS}

Table 1: Milk sero-prevalence of brucellosis in small dairy herd samples

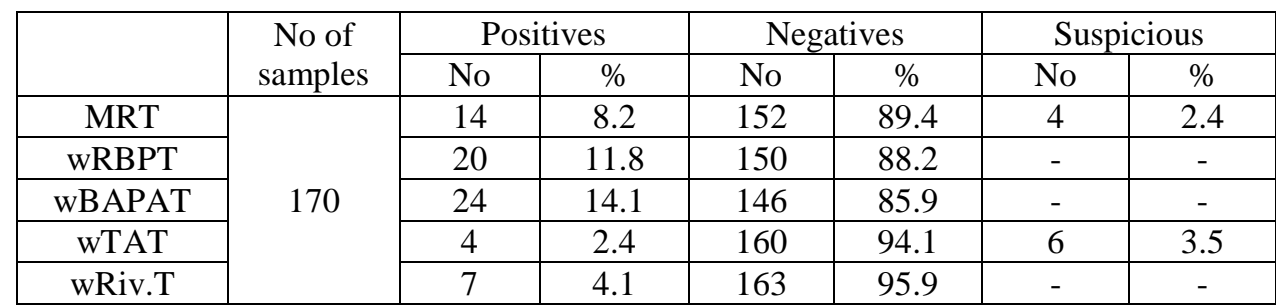

Table 2: Milk sero-prevalence of brucellosis in retail milk samples 


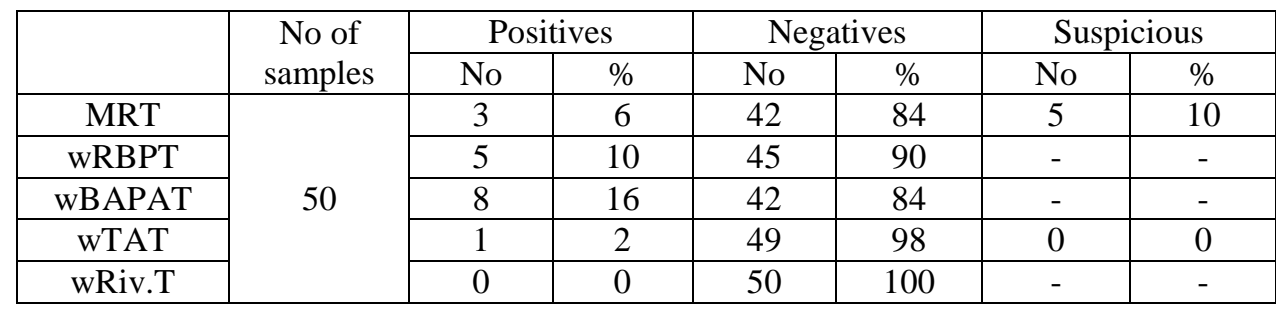

\section{DISCUSSION}

Since brucellosis was first recorded in Egypt by Ahmed (1939), it remains an important public health and animal problem and received special attention in the last three decades due to higher incidence of brucellosis associated with cattle importation in open door policy for establishment of intensive breeding farms.

The results summarized in Table (1) revealed that $14(8.2 \%)$, $20(11.8 \%), 24(14.1 \%), 4(2.4 \%)$ and $7(4.1 \%)$ out of 170 small dairy herds samples were positive for MRT, wRBPT, w BAPAT, wTAT and w Riv.T respectively.

On the basis of MRT nearly similar results were reported by Robertson, et al. (1980) and Abdel-Hakiem (1999), as they found MRT positive in 8.42 and $8 \%$ of milk samples respectively. Higher prevalence (11.4\%) was recorded by Salem, et al. (1987), 10\% by Hamdy (1992), $29.2 \%$ by El-Sheery (1993), 38.33\% by Abdel-All (2001) and $12.38 \%$ by El-Bassiony, et al. (2007). On the other hand, lower prevalence (0.2\%) was recorded by Awad, et al. (1977), 4\% by Bastawrous (1987), $4.1 \%$ by Hosein and El-Kholy (1993), $4.31 \%$ by Gandara, et al. (1994) and $0.99 \%$ by Kadry (1996).

Several investigators referred to MRT as simple, rapid, accurate, highly sensitive, reliable and useful tool for detecting brucella agglutinins in milk of individual cows or herds (Ferguson and Robertson, 1954, Nicoletti and Burch, 1969, Morgan et al., 1978, Boraker et al., 1981, Salem et al., 1987, El-Gibaly et al., 1991, Hamdy (1992), Hosein and El-Khoy, 1993, Osman et al., 1997, Abdel-Hakiem, 1999 and Bandara and Mahipala, 2002 ).

It also gave false positive reaction when the samples were taken near the end of lactation period, from mastitic milk quarters, shortly after parturition, from cows with hormonal disorders or when the colostrum included in the samples (Keer et al., 1959, Bercovich and Moerman 1979, Corbel et al., 1984 and Mac Millan, 1990), which are avoided during samples collection in this study. 
Concerning the results of the wRBPT, lower values 4.7 and 4.29\% were recorded by Abdel-Hakiem (1999) and El-Bassiony et al. (2007) respectively, while higher value $(22.1 \%)$ was recorded by Abdel-Rahman (1991).

Regarding wBAPAT lower value (4.29\%) was obtained by El-Bassiony et al. (2007), while higher value (38.9\%) was recorded by Abdel-Rahman (1991).

In case of wTAT, nearly similar result $(2.2 \%)$ was recorded by Turutoglu et al. (2003), while higher results (5.24 and 28.6\%) were recorded by El-Bassiony et al. (2007) and Abdel-Rahman (1991) respectively. Moreover, nearly similar results to wRiv.T were recorded by Abdel-Hakiem (1999) (4\%) and El-Bassiony et al. (2007) (4.29\%).

Shifting to the results summarized in Table 2, $3(6 \%), 5(10 \%)$, $8(16 \%), 1(2 \%)$ and $0(0 \%)$ out of 50 retail milk samples were positive for MRT, wRBPT, w BAPAT, wTAT and w Riv.T respectively.

The results reported herein are higher than those reported by Abd-Alla et al. (2000) in case of MRT and wRBPT, while lower in case of wRiv.T, as they reported 3.67, 3.53 and 2.86\% with MRT, wRBPT and wRiv.T, respectively. On the other hand, Mishra (1982) and Arimi et al. (2005) pointed out higher prevalence of brucellosis (7 and 12.3\% respectively) by using MRT.

There were some differences in the reactions from one test to another, which may be attributed to inability of some bovine antibodies subisotypes to be detected by all tests. IgG1, a very important subisotype, could be detected by RBPT, BAPAT and Riv.T but missed by TAT and MRT. IgG2, (relatively less important subisotype), could be detected by TAT, RBPT, BAPAT and Riv.T. IgM which is a cause of false positive, but its importance came from its presence at a very early stage of infection, IgM could be detected by MRT and TAT but not by RBPT and Riv.T (EL-Enbaawy et al., 1995). IgA in milk does play an important role in the MRT, IgM also participates in this reaction (FAO/WHO, 1986). In addition to defattening process before the preparation of whey, removal of the solid part using rennin, the changes in $\mathrm{pH}$, the changes in the molecular weight of immunoglobulins and most of the milk immunoglobulins are present on the surface of the fat globule (Sutra et al., 1986, Hamdy, 1997and Abdel-Hakiem, 1999).

In conclusion, this study showed that the milk of small dairy herds and retailers in both examined cities play a dangerous role in transmitting infection to man, so efficient boiling or pasteurization of milk before consumption especially in infected areas to safeguard the 
consumers, urgent need for effective program for the control of this disease in reservoir animals in Egypt and educational programs to those sharing in milk production and handling as well as processing of dairy products. Further studies on brucellosis should be conducted in other areas for setting up priorities for control measures.

\section{REFERENCES}

Abd-Alla, M.M.; Mousad, A.A. and Mountaser, A.M. (2000): Incidence and characterization of brucella microorganisms in raw milk and kariesh cheese. Beni-Suef Vet. Med. J., X (1), 41-49.

Abdel-All, A.A.A. (2001): Prevalence of Brucella organisms in milk and some dairy products. Ph.D., Thesis, Fac. Vet. Med., Cairo Univ., Egypt.

Abdel-Hakiem, E.H. (1999): The role of cow's raw milk in transmission of brucellosis. J. Agriculture in the tropics and subtropics. 69, 33-41.

Abdel-Rahman, M.A. (1991): Some epidemiological aspects of bovine brucellosis. M.V.Sc., Thesis, Fac. Vet. Med., Cairo Univ., Egypt.

Ahmed, M.R. (1939): The incidence of brucellosis in different domesticated animals in Egypt. Tech. Bull., 23, 210-231.

Alton, G.G.; Jones, L.M.; Angus, R.D. and Verger, I.M. (1988): Technique for the brucellosis Laboratory. INRA publication, Paris, France.

Altuglu,I.; Zeytinogclu, A.; Bilgic, A.; Kamcioglu, S.; Karakartal, G. and Smits, H. (2002): Evaluation of Brucella dipstick assay for the diagnosis of acute brucellosis. Diagnostic Microbiology and infectious disease, 44, 241-243.

Arimi, S.M.; Koroti, E.; Kang ethe, E.K.; Omore, A.O. and McDermott, J.J. (2005): Risk of infection with Brucella abortus and Escherichia coli O157: $\mathrm{H} 7$ associated with marketing of unpasteurized milk in Kenya. Acta Tropica, 96, 1-8.

Awad, F.I.; Amin, M.M.; Shawkat, M.E.; Fayed, A.A. and Matter, A.A. (1977): Comparative studies on milk ring test and agglutination tests in the diagnosis of brucellosis in cattle and buffaloes in Egypt. Egypt. J. Vet. Sci., 14:2, 135-140.

Bandara, A.B. and Mahipala, M.B. (2002): Incidence of brucellosis in Sri Lanka: an overview. Vet. Microbiol., 20: 90 (1-4), 197-207. Bastawrous, A.F. (1987): A study on the prevalence of brucellosis among dairy farm animals in Alexandria. M.D., of public 
health science "food hygiene", High Institute of Public Health, Alexandria Univ., Egypt.

Bercovich, Z. and Moerman, A. (1979): Non specific positive ring tests in tank milk and Estrumate in the treatment of cattle. Tijdschr. Diergeneesk., 104, 713-716.

Boraker, D.K.; Stinebring, W.R. and Kunkel, J.R. (1981): BrucELISA: an Enzyme Antibody Immunoassay for detection of Brucella abortus antibodies in milk: correlation with the Brucella ring test and with shedding of viable organisms. J. Clinic. Microbiol., 14: 4, 396-403.

Corbel, M.I.; Staurt, F.A. and Brewer, A.A. (1984): Observations on serological cross reactions between smooth Brucella species and organisms of other genera. Dev. Biol. Stand., 56, 341-349.

Davies, G. (1971): The Rose Bengal test. Vet. Rec., 88, 447-449.

El-Bassiony, T; El-Prince, E.; Zein El-Abdeen, S. and Sadek, O.A. (2007): Diagnosis of Brucella infection in dairy cattle with serological tests in Assiut Governorate. Assiut Vet. Med. J., 53: 114, 167-180.

El-Enbaawy, M.; El-Jakee, J.; Fayed, A.A. and Refai, M.K. (1995): Evaluation of competitive ELISA, in comparison with other conventional serological tests, for detection of bovine brucellosis in Egypt. J. Egypt. Vet. Med. Assoc., 55: 3, 769780.

El-Gibaly, S.; Salem, A.A.; Etman, R.H.; Hosein, H.I. and Ibrahim, S.I. (1991): effect of milk dilution on the reaction of milk ring test for brucellosis. Beni-Suef Vet. Med. Res., 1:1, 131-135.

El-Sheery, M.N.S. (1993): Some studies on the relationship between brucellosis and other affection in farm animals. Ph.D. Thesis, Fac. Vet. Med., Suez Canal Univ., Egypt.

FAO/WHO (1986): An expert committee on brucellosis. $6^{\text {th }}$ Ed.

Ferguson, G.S. and Robertson, A. (1954): The use of milk ring test in a survey of the incidence of bovine brucellosis in southern Scotland. J. Hyg. Comb., 52, 14-36.

Gandara, B.; Zheludkov, M.M. and Chernycheva, M.I. (1994): An evaluation of the effectiveness of laboratory diagnostic methods for brucellosis. Zhurnal Mikrobiol. Epidemiol. Immunobiol., 4: 55-58.

Hamdy, M.E.R (1992): Epidemiological studies on Brucella melitensis in dairy animals and man. Ph.D. Thesis, Fac. Vet. Med., Cairo Univ., Egypt. 
Hamdy, M.E.R. (1997): Correlation between humoral and cellular immune response in dairy cows naturally infected with Brucella abortus. Egypt. J. Egypt. Vet. Med. Assoc., 57:1, 331349.

Hosein, H.I. and El-Kholy, A.M. (1993): Studies on bovine brucellosis in middle Egypt. $4^{\text {th }}$ symposium on food pollution, 15-16 Nov., Assiut Univ., Egypt.

Kadry, M.B. (1996): Some studies on brucellosis in cattle and buffaloes. M.V.Sc., Thesis, Fac. Vet. Med., Cairo Univ., Egypt.

Keer, W.R.; Pearson, J.K.L. and Rankin, J.E.F. (1959): The bovine udder and its agglutinins. Brit. Vet. J., 115, 105-119.

Mac Millan, A. (1990): Conventional serological tests. In: ed. Nielsen K.H. and Duncan, J.R., Animal Brucellosis, CRC press. Boca Raton. FL.

Mishra, K.C. (1982): Incidence of brucellosis in milk shed areas of Sikkim: a preliminary report. Indian Vet. Med. J., 6: 3, 168170.

Morgan, W.J.B.; Mackinnin, D.J. and Cullen, G.A. (1969): The Rose Bengal plate agglutination test in the diagnosis of brucellosis. Vet. Rec., 85, 636-641.

Morgan, W.J.B.; Mackinnin, D.J.; Gowar, S.G. and Norris, P.I. (1978): Brucellosis diagnosis standard laboratory techniques. Report series No. 1, weybrige Cent. Vet. Lab., England.

National Veterinary Services Laboratories, Ames, Iowa, USA (1984): Instructions manual on conducting brucellosis serological tests.

Nicoletti, O. and Burch, G.E. (1969): A comparison of the tube agglutination supplemental and brucellosis ring test in selected dairy herds in New York. Cornell Vet., 59, 349-354.

Nielsen, K. ; Smith, P.; Gall, D.; Perez, B.; Cosma, C.; Mueller, P.; Trottier, J.; cote, G.; Boag, L. and Bosse, J. (1996): Development and validation of an indirect enzyme immunoassay for detection of antibody to Brucella abortus in milk. Vet. Microbiol., 52, 165-173.

Osman, K.M.; Shalabi, M.N.H.; El-Jakee, J.; Saad, M.A.M.; Ibrahim, I.G.A.; Bassiony, M.M. and Abdel-Hameid N.A. (1997): Efficiency of abortus bang ring test and whey agglutination test in detection of brucella infected cows and buffaloes. Egypt. Soc. Anim. Reprod. Fert., 9 ${ }^{\text {th }}$ annual congress, 12-14, Feb., Giza, Egypt. 
Robertson, L.; Farrell, I.D.; Hinchliffe, P.M. and Quaife, R.A. (1980): Bench book on Brucella. Vet. Rec., 104, 56-58. (Cited after El-Bassiony et al., 2007).

Salem, A.A.; El-Gibaly, S.M.; Hassan, M.S. and Hosein, H.I. (1987): Sensitivity of some diagnostic procedures for brucellosis in cattle. Assiut Vet. Med. J., 18: 36, 159-162.

Sanders, R.B. (1989): Pathogenesis and epidemiology of brucellosis. Brucellosis seminar, Cairo, Egypt, February.

Smith, B.P.; Oliver, D.G. and Singh, P. (1989): Detection of Salmonella Dublin mammary gland infection in carrier cows. Using an enzyme linked immunosorbent assay for antibody in milk and serum. Am.J. Vet. Res., 50, 1352.

Sutra, L.; Caffin, J.P. and Dubray, G. (1986): Role of milk immunoglobulins in the Brucella milk ring test. Vet. Microbiol., 12, 359-366.

Turutoglu, I.I.; Mutluer, B. and Uysal, Y. (2003): Investigation of Brucella infection in milk collected from Burdur Province. Turk. J. Vet. Anim.Sci., 27: 1003-1009. 